Volume 6 Issue 4, December 2019

Nationally Accredited Journal,

Decree No. B/4130/E5/E5.2.1/2019

\title{
Legal Certainty Of Notary That Leave Because Inducted Into Legislature
}

\author{
Wella Tiara Aginta ${ }^{1}$ and Akhmad Khisni ${ }^{2}$
}

Abstract. The purpose of this study were 1) to analyze and explain the legal certainty of the notary who leave because inducted into the legislature. 2) To analyze and explain the barriers and solutions to the notary who leave because inducted into the legislature. The method used by researchers is normative legal approach and specification in this study were included descriptive analysis. The sources and types of data in this research is secondary data obtained from the study of literature. Based on the results of research that Legal certainty to the notary who leave because inducted into the legislature is always referred substitute notary replaced and the decree was not revoked. Normative, legal certainty it requires the availability of devices legislation which is operationally able to support its implementation. Empirically the existence of legislation that need to be consistent and inconsistent human resources and supporting Notary Supervisory Council. In the execution of a notary who leave because inducted into the legislative, which makes barriers in this issue, namely: a) Could not intensively guiding the deed made by the notary substitute; b) Can not make corrections formal and substantive evidence against the deeds were made but the name remained imprinted substitute notary; c) Can not guarantee against legal certainty to the deed made by the notary substitute; d) Can not / are not able to use the time off was good. Solutions to overcome barriers to notaries who leave because inducted into the legislature is to reinforce the requirement for nominating a member legislative, not just for not practicing (on leave) but with resignation as a notary or PPAT and release all the attributes (nameplate, office practices, and so on ).

Keywords: Rule of Law; Notaries; Leave; Legislature.

\section{Introduction}

The Republic of Indonesia is a country of law, the principle of rule of law, ensure certainty, order and legal protection that core truth and justice. Through a deed made Notary must provide legal certainty to the user community Notary services. ${ }^{3}$

Early Notary is essentially a public official (private Notary) assigned by the general power to serve the needs of the community that provide authentic evidence of civil legal certainty. So all the authentic evidence is still required by the country's legal system the Notary office will still be needed existence in society. Historically, the notary is a State officials to perform the duties of the State in the public service in order to create legal certainty as an authentic deed officials in the civil case. ${ }^{4}$

A Notary Public is appointed and dismissed by a public authority in this case is the Government, the Minister of Justice and Human Rights of the Republic of Indonesia, in this thesis referred to the Minister, the presence of a Notary is the implementation of the rules of evidence. ${ }^{5}$

Notary by law granted the right to leave with the overall amount of time off later than

\footnotetext{
${ }^{1}$ Student Master of Notary Program, Faculty of Law, UNISSULA, Email: w.agyn@yahoo.com

2 Lecturer, Faculty of Law, Sultan Agung Islamic University, Semarang.

${ }^{3}$ Salim H. and H. Abdulah, 2007, Perancang Kontrak dan MOU, Jakarta: Sinar Grafika, p.101102

${ }^{4}$ Hartati Sulihandari, 2013, Prinsip-Prinsip Dasar Profesi Notaris, Jakarta: World Smart, p 4

${ }^{5}$ Herlien Boediono, in 2013, Kumpulan Tulisan Hukum Perdata di Bidang Kenotariatan Buku Kedua, Bandung: Citra Aditya Bakti, p. 220.
} 
twelve (12) years during his run. Notaries can take leave annually or once for several years. However, any decision on leave later than five (5) years have included extension. With the provision of leave entitlements can be taken when the Notary has run his post for two (2) years. Therefore, if a Notary wants to use his leave right then he is obliged to perform his first and obliged to appoint Substitute Notary.

Terms of Submission of Application leave provided for in Article 30 UUJN, namely:

- On each application for leave shall include a certificate that contains a notice of leave earlier

- The certificate is issued by the Minister and at leave recently added a note of it by the competent authorities give leave

Procedure leave Notary begins with applying for leave in writing with the proposed appointment of Substitute Notary to the authorities, the Council of Regional Supervisor, in which case the period of leave not more than six (6) months, the Assembly of Trustees Territory, in which case the period of leave over 6 (six) months to one (1) year, or the council of the Supervisory Center, if leave more than 1 (one) year. Leave requests to the Regional Supervisory Council Supervisory Council forwarded to the Center. Leave requests to the Central Council forwarded to the Assembly and the Regional Regional Supervisory Council. ${ }^{6}$

Notary applying for leave are required to submit leave requests reports as well attach a certificate of leave and must be received by the competent authority, in this case the Supervisory Council within a period of 30 (thirty) days before the time off begins. Notaries may be appealed to the Regional Supervisory Council if the request for leave was denied, with a notes of rejection is issued by the Regional Supervisory Council. This applies if the refusal of leave requests issued by the Regional Supervisory Council, the Notary applying for such leave may be appealed to the Central Supervisory Council. Based on the background of the problems mentioned above, then the problem can be formulated as follows: How can the rule of law against the notary who leave because inducted into the legislature? How the barriers and solutions to the notary who leave because inducted into the legislature?

\section{Research methods}

The approach which I use in the preparation of the writing of this legal research is a normative legal research, as in the study of law conceived as regulations are normative and as the norms of writing created and promulgated by an agency or by officials of the state authorities, the law is seen as an autonomous institution, regardless of the other agencies in the community. Therefore, the assessment is done, only "limited" in the legislation (written). This research is descriptive research that aims to paint a picture of the state of things on certain areas and at certain times.

\section{Results and Discussion}

\subsection{Notary The Legal Certainty Of Leaves For Being Inducted Into Legislature}

Legal certainty is a question that can only be answered in a normative, not sociological. Normative legal certainty is when a rule is made and enacted exactly as set out clear and logical. Obviously in the sense not cause doubts (multi-interpretation)

\footnotetext{
${ }^{6}$ Ngadino, 2019, Tugas dan Tanggung Jawab Notaris di Indonesia, First Edition, Semarang: UPT Press, p. 28
} 
Volume 6 Issue 4, December 2019

Nationally Accredited Journal,

Decree No. B/4130/E5/E5.2.1/2019

and logical in the sense that it becomes a system of norms the other norms that do not clash or conflict norm. Conflict norms arising from the uncertainty of rules can be shaped contestation of norms, reduction or distortion norm.

In terms of decision-leave should Notaries are applying for leave to assembly supervisor, if a Notary does not request leave it thus Notary has violated the provisions in the UUJN which states that a Notary is forbidden to leave the premises during the seven (days) consecutive working without any valid reason according contained within Article 17 point $b$.

Regarding leave in here not explained well the sanctions related to the nomination of Substitute Notary, because in fact one does not propose Substitute Notary Public Notary, in the absence of Substitute Notary because of the trustworthy. Such Notary in asking leave yet up to 2 (two) years running the position so excuse the lack of trust as a basis for not using Substitute Notary proposal. as well as with the Supervisory Council of Regions in an arbitrary, Regional Supervisory Council is authorized to designate the Substitute Notary defined in Article 70 UUJN c, d, and f.

According to the Regulation of the Minister of Law and Human Rights No. 25 of 2014 on the Procedures of Appointment, Transfer Notary. ${ }^{7}$ Article 23 in terms of leave application, MPD, MPP, or MPW issued a determination letter and the appointment of Substitute Notary leave for long periods 14 days from the date of filing the leave. then notaries who apply for sabbatical leave must submit a report to the Minister by completing the Entry Format Report on leave.

The existence of that article need to be clear, what is in urgent circumstances here, so that a Notary may ask leave of absence. According to Indonesian dictionary meaning of the word urgent is forced to immediately do (Loaded, completed because in an emergency, critical, and so on), in urgent circumstances, one should quickly take a decision.

In connection with the responsibilities of the legal profession will be presented the scope of responsibility of members of the Regional Representatives Council (hereinafter referred to as DPRD) who wants to become a notary. Based on the historical development of the constitutional concept of the separation of powers proposed by Montesquieu in his book entitled "L'Espirit des Lois". Montesquieu divides state power into three branches, namely: the legislative power as the creator of the Law (DPR and DPRD), who carry out executive power (President and Head of Region), the power to judge or judicial (law enforcement agencies). This is known from Montesquieu classification division of the modern state power in three functions, namely the legislative, executive, and judicial. ${ }^{8}$

Functionally, a notary public and legislators alike as officials, notaries as public officials according to Law No. 30 of 2004 on the office of a notary, while legislators as local authorities pursuant to Law No. 23 of 2014 on local government. However, notaries and legislators have a duty and authority completely different. Notary engaged in private law, legislators have a function as the body of legislation relating to the law known public. Such as, notary in Indonesia belonging to the Latin notary, which, according to Black was the one who recorded what was said by another person or people who copy what was written by someone else. ${ }^{9}$ From the functional side, the Parliament has a legislative function, budgetary, and oversight.

7 Regulation of the Minister of Law and Human Rights No. 25 of 2014 About the ordinance appointment And Displacement Notary

${ }^{8}$ Son Astomo, 2014, Hukum Tata Negara (Teori dan Praktek), Yogyakarta : Thafa Media, p. 12. ${ }^{9} \mathrm{GHS}$ Lumban Tobing, 1983, Peraturan Jabatan Notaris, Jakarta: Erlangga p. 34. 
Article 11 (1) of Law No. 2 of 2014 On Notary states that notaries who was appointed state officials are required to take leave. leave referred to in paragraph (1) shall be valid for Notary served as state officials subsection (2). notary referred to in paragraph (1) shall appoint a substitute Notary. elucidation of Article 11 paragraph (1) provisions that are intended to avoid conflicts of interest as a Notary Public, he is obliged to be independent and impartial.

UUJN also arranged for a Notary who was appointed the State Officials. If the Notaries concurrently with public office, this is one to suspend Notary of the position (article 8, paragraph (1) letter e UUJN). If a Notary will be appointed as State officials then required to take leave after he took as a state official (Article 11 (1) and (2) UUJN), and shall appoint the Notary replacement will receive the protocol, and after no longer assume office as Acting country, the Notary can carry on the task the position as Notary (Article $11(3)$ - (6) UUJN). The provisions of this kind to keep the continuity of the Notary office.

Especially for notaries who ask leave of absence during the twelve (12) years later application for leave was rejected by the Board of Trustees Center, the Notary shall file a leave of absence for the period in question served as state officials and will be suspended from the position, and protocol will be submitted to another notary, a notary who received the protocol shall be handed back to the notary who has completed his duties as a state official.

Notary watchdog Assembly as the only institution authorized to conduct supervision, inspection and sanctions against notaries, each level of the Supervisory Council (MPD, MPW and MPP) have the authority respectively. ${ }^{10}$

MPD is set in UUJN authority, regulation of the Minister of Justice and Human Rights of the Republic of Indonesia Number M.02.PR.08.10 2004, and the decision of the Minister of Justice and Human Rights of the Republic of Indonesia No. M.39-PW.07.10. 2004. As in Article 13 paragraph (1) and (2), which affirms that the authority of an administrative nature MPD held by the chairman, vice chairman or a member who is authorized by the MPD meeting decisions, namely concerning:

- Giving permission until leave for a period of 6 (six) months;

- Setting a substitute notary;

- Specify where to save the Notary Protocol at the time of the handover protocol notary are aged 25 (twenty five) years or more;

- Receive reports from the public regarding the alleged violation or breach Notary Code provisions in the legislation;

- Provide initial and sign the certificate list, a list of certificates, a list letter under the hand that was passed, the list of the letter under the hand, which were recorded and the list of other documents which are required by law;

- Accepting delivery of a written copy of your letter which was recorded under the hand that has been certified by him, which was made in the previous month later than fifteen (15) calendar days of the following month, which includes at least the number, date and title deed.

If observed from each article related to leave in UUJN there are several chapters that need to be considered, as in article 28 is not described in more detail related to the leave application so this needs to be measured the extent to which such article can be implemented. So that the necessary legal certainty. Legal certainty to the notary who leave because inducted into the legislature is always referred substitute notary

\footnotetext{
${ }^{10}$ Habib Adjie, 2011, Majelis Pengawas Notaris Sebagai Pejabat Tata Usaha Negara, Bandung: Rafika, p 6-16
} 
Volume 6 Issue 4, December 2019

Nationally Accredited Journal,

Decree No. B/4130/E5/E5.2.1/2019

replaced and the decree was not revoked. Normative, legal certainty it requires the availability of devices legislation which is operationally able to support its implementation. Empirically the existence of legislation that need to be consistent and inconsistent human resources and supporting Notary Supervisory Council.

\subsection{Obstacles And Solutions to the Notary that leave Because Inducted as Legislature}

During the run the position, a notary is entitled to take the leave, which can be taken after stints the position for 2 (two) years. The total number of leave taken Notary no more than twelve (12) years. Notary office in accordance with the character that must be sustainable over the Notary still in the position, the Public Notary concerned shall appoint a substitute. ${ }^{11}$

Every Notary has the right to leave, the right to leave as mentioned in Article 25 UUJN. may be taken after the Notary run the position for 2 (two) years. during the run leave Notary must propose a replacement. Notaries are also allowed if it does not want to take the sabbatical rights, but less likely if the notary does not take its leave rights.

Leave requests can be accepted or rejected by the MPD, MPW, or MPP because it does not meet the requirements of Article 15 and Article 16 of the Regulation of the Minister of Law and Human Rights No. 25 of 2014 About Terms and Procedure for Appointment, Transfer, Dismissal, and Extension of Term Notary Public. Against the rejection of MPD, MPW, or MPP issued a rejection letter on leave along with the reasons of rejection. ${ }^{12}$

Based No.M.01 permenkuham-HT.03.01 2006 Article 41, the notary who apply for leave to the minister. Director General of the leave is to attach a copy of the certificate of leave authorized by the Supervisory Council of Notaries in a period of 30 (thirty) days from the leave granted. ${ }^{13}$

In the execution of a notary who leave because inducted into the legislative, which makes barriers in this issue, namely:

- Could not intensively guiding the deed made by the notary substitute

- Can not make corrections formal and substantive evidence against the deeds were made but the name remained imprinted substitute notary.

- Can not guarantee against legal certainty to the deed made by the notary substitute

- Can not / are not able to use the time off was good

Solutions to overcome barriers to notaries who leave because inducted into the legislature is to reinforce the requirement for nominating a member legislative, not just for not practicing (on leave) but with resignation as a notary or PPAT and release all the attributes (nameplate, office practices, and so on ).

\section{Closing}

\subsection{Conclusion}

- Legal certainty to the notary who leave because inducted into the legislature is

\footnotetext{
${ }^{11}$ Habib Adjie, 2008, Hukum Notaris Indonesia Tafsiran Tematik Terhadap UU No. 30 Tahun 2004 tentang Jabatan Notaris, Bandung: Refika Aditama, p 99.

12 Regulation of the Minister of Law and Human Rights No. 25 of 2014 About Terms and Procedure for Appointment, Transfer, dismissal, and Extension of Term Notaris, Article 21

${ }^{13}$ Hartanti Sulihandari \& Nisya Rifani.Op Cit., P 73
} 
always referred substitute notary replaced and the decree was not revoked. Normative, legal certainty it requires the availability of devices legislation which is operationally able to support its implementation. Empirically the existence of legislation that need to be consistent and inconsistent human resources and supporting Notary Supervisory Council.

- Obstacles And Solutions To The Notary That leave Because Inaugurated as Legislature; In the execution of a notary who leave because inducted into the legislative, which makes barriers in this issue, namely: Could not intensively guiding the deed made by the notary substitute; Can not make corrections formal and substantive evidence against the deeds were made but the name remained imprinted substitute notary; Can not guarantee against legal certainty to the deed made by the notary substitute; Can not / are not able to use the time off was good Solutions to overcome barriers to notaries who leave because inducted into the legislature is to reinforce the requirement for nominating a member legislative, not just for not practicing (on leave) but with resignation as a notary or PPAT and release all the attributes (nameplate, office practices, and so on ).

\subsection{Suggestion}

- In order to ensure legal certainty for Substitute Notary supposed to be the inauguration of re-Acting Notary. There are differing opinions about whether or not related to the inauguration of Acting Substitute Notary Public Notary. According to the views of the academics that Substitute Acting Notary should no longer inauguration as caretaker to replace notaries who is inducted into the legislature at the time of running off. But in terms of implementation in this case represented by the Regional Office of the Minister who inaugurated, it will not come back as Substitute Notary appointment as Acting Notary had become one unit.

- Regional Supervising Assembly should be present at the time of delivery to the recipient Protocol Notary Protocol to synchronize the number of certificates submitted in accordance with the handover protocol news of the signing, in order to avoid inconsistency of data which is a state archive.

\section{References}

[1] GHS Lumban Tobing, 1983, Peraturan Jabatan Notaris, Erland, Jakarta

[2] Salim H. and H. Abdulah, 2007, Perancang Kontrak dan MOU, Graphic Rays, Jakarta

[3] Habib Adjie, 2008, Hukum Notaris Indonesia Tafsiran Tematik Terhadap UU No. 30 Tahun 2004 tentang Jabatan Notaris, Refika Aditama., Bandung

[4] , 2011, Majelis Pengawas Notaris Sebagai Pejabat Tata Usaha Negara, Rafika, Bandung.

[5] Hartati Sulihandari, 2013, Prinsip-Prinsip Dasar Profesi Notaris, Jakarta: World Smart

[6] Herlien Boediono, 2013, Kumpulan Tulisan Hukum Perdata di Bidang Kenotariatan Buku Kedua, Bandung: Citra Aditya Bakti

[7] Ngadino, 2019, Tugas dan Tanggung Jawab Notaris di Indonesia, First Edition, Semarang: UPT Press

[8] Son Astomo, 2014, Hukum Tata Negara (Teori dan Praktek), Thafa Media, Yogyakarta. 